\title{
PEMBUATAN TURBIN ANGIN SUMBU VERTIKAL DENGAN VARIASI JUMLAH SUDU DAN SISTEM BUKA-TUTUP SIRIP
}

\author{
Bono , Gatot Suwoto \\ Jurusan Teknik Mesin, Politenik Negeri Semarang \\ Jl. Prof Sudarto, S.H Tembalang. Kotak Pos 6199/SMS, Semarang 50329 \\ Telp. 7473417, 7466420 (Hunting), Fax. 7472396
}

\begin{abstract}
Abstrak
Turbin angin sumbu vertikal dengan variasi jumlah sudu dan sistem buka tutup sirip adalah suatu alat konversi energi yang mengubah energi gerak dari sudu turbin menjadi energi listrik. Tujuan dari tugas akhir ini adalah untuk membuat turbin angin sumbu vertikal tipe sudu bersirip dengan jumlah variasi jumlah sudu dan menguji kinerja turbin angin tersebut. Pada penelitian ini menggunakan metodelogi penelitian kuantitatif dengan cara mengumpulkan data. Variabel bebas pada penelitian ini adalah jumlah sudu 2, 3, 4, 5,6 dan kecepatan angin $7 \mathrm{~m} / \mathrm{s}, 8 \mathrm{~m} / \mathrm{s}, 9 \mathrm{~m} / \mathrm{s}, 10 \mathrm{~m} / \mathrm{s}, 11 \mathrm{~m} / \mathrm{s}$, dan $12 \mathrm{~m} / \mathrm{s}$. Variabel terikat pada penelitian ini adalah unjuk kerja turbin angin sumbu bersirip yaitu daya kinetik, daya generator dan efisiensi. Sedangkan variabel terkontrolnya adalah jumlah sudu pada turbin angin tipe sudu bersirip sebanyak 6 buah dengan tinggi $600 \mathrm{~mm}$ dan lebar $300 \mathrm{~mm}$. Hasil penelitian ini menunjukkan bahwa pengujian menggunakan jumlah sudu yang berbeda-beda mempengaruhi unjuk kerja turbin angin tipe bersirip. Efisiensi sistem tertinggi diperoleh pada jumlah sudu 3 sebesar 1,409\% pada kecepatan $11 \mathrm{~m} / \mathrm{s}$.Daya tertinggi pada turbin angin diperoleh dengan jumlah sudu 6 sebesar 6,6 watt pada kecepatan angin $12 \mathrm{~m} / \mathrm{s}$ dengan putaran generator $202.92 \mathrm{rpm}$ pada beban 30 watt. Berdasarkan analisa, efisiensi maksimal turbin angin hanya dapat dicapai jika intensitas angin konstan sehingga menghasilkan tegangan dan arus yang besar.
\end{abstract}

Kata kunci : Turbin ,Sudu, Sirip, Daya, Efisiensi .

\section{Pendahuluan}

\section{Latar Belakang}

Energi angin telah lama dikenal dan dimanfaatkan manusia. Misalnya sebagai penggerak perahu-perahu layar untuk mengarungi luasnya lautan. Selain itu, energi angin juga dapat digunakan sebagai pembangkitlistriktenagaalternatif.

Salah satunya adalah turbin angin tipe bersirip. Turbin ini merupakan turbin dengan sumbu vertikal dengan sirip-sirip yang ada disetiap sudunya. Turbin ini memiliki poros atau sumbu rotor utama yang di susun tegak lurus terhadap permukaan tanah. Kelebihannya adalah turbin ini mampu mendayagunakan angin dari berbagai arah.
Performa dari turbin ini sendiri dapat dilihat dari daya listrik yang di hasilkan oleh generator dan effisiensi sistem.

Penelitian sebelumnya dilakukan variasi terhadap kecepatan, variasi jumlah sirip, variasi lebar sudu dan variasi panjang sudu. Pada penelitian ini akan di lakukan variasi terhadap jumlah sudu turbin angin sumbu vertikal dengan tipe sudu bersirip yaitu 2, 3, 4, 5 dan 6 sudu.

Penelitian ini dimaksudkan untuk mengetahui berapa jumlah sudu pada turbin angin sumbu vertikal dengan

tipe sudu bersirip agar dapat mencapai kerja maksimal. 


\section{Batasan Masalah}

- Penulis hanya membahas pengaruh kecepatan angina terhadap putaran generator dandayalistrik yang dihasilkan.

- Penulis hanya membahas pengaruh variasi jumlah sudu, yaitu jumlah sudu 2, 3, 4, 5 dan 6 terhadapdayalistrik. Sehingga di dapat jumlah sudu yang paling baik.

\section{Tinjauan Pustaka}

\section{Penelitian Sebelumnya}

TjukupMarnoto (2011), meneliti tentang turbin angin bilah bersirip dengan variasi panjang $(0,3 \mathrm{~m} ; 0,215 \mathrm{~m} ; 0,155 \mathrm{~m})$, lebar bilah $(0,3 \mathrm{~m} ; 0,25 \mathrm{~m}$; dan $0,2 \mathrm{~m})$, jumlah sirip tiap bilah $(10,7,5)$ dan variasi kecepatan angin antara 3,1-7,8 $\mathrm{m} / \mathrm{s}$ dengan tujuan untuk mengetahui efisiensi, daya generator dan torsi. Hasil penelitian menyimpulkan bahwa kincir angin bilah bersirip dapat berputar mulai kecepatan $3,1 \mathrm{~m} / \mathrm{s}$ dan efisiensi mencapai $2,17 \%-23,54 \%$.

Lalu, Trifiananto Muhammad (2012), meniliti tentang turbin angin tipe bilah bersirip dengan variasi kecepatan angin $3,4,5,6,7 \mathrm{~m} / \mathrm{s}$ dan variasi panjang bilah 0,$15 ; 0,2 ; 0,25 \mathrm{~m}$ telah diperoleh daya poros tertinggi yang dicapai turbin dengan panjang bilah $0,25 \mathrm{~m}$ yaitu sebesar 3,05 x 10-3 Watt pada kecepatan $7 \mathrm{~m} / \mathrm{s}$. Torsi yang tertinggi di capai oleh turbin dengan panjang bilah $0,25 \mathrm{~m}$ dan kecepatan $7 \mathrm{~m} / \mathrm{s}$ yaitu sebesar 1,53 x 10-4 $\mathrm{Nm}$. Untuk efisiensinya yang tertinggi diperoleh pada bilah dengan panjang 0,25 $\mathrm{m}$ dan kecepatan angin $4 \mathrm{~m} / \mathrm{s}$ sebesar $1,84 \times 101 \%$.

Kemudian Dani Kurniawan (2014), dengan variasi jumlah bilah, variabel bebas dalam penelitian ini adalah variasi kecepatan angin sebesar 3, 4, 5, 6, dan 7 $\mathrm{m} / \mathrm{s}$ serta jumlah sirip 3 buah, 5 buah, dan 7 buah. Pada pengujian ini daya poros, torsi, dan efisiensi tertinggi tercapai pada jumlah sirip sebanyak 7 buah, panjang dan lebar masing-masing adalah $25 \mathrm{~cm}$ dan $6 \mathrm{~cm}$ dengan suhu ruangan $27^{\circ} \mathrm{C}$.
Lalu, Yashero Muttaqin (2015), meneliti tentang turbin angin tipe bilah bersirip dengan variasi lebar bilah yaitu 4, 5, dan 6 cm dengan kecepatan angin 3, 4, 5, 6, dan 7 $\mathrm{m} / \mathrm{s}$. Pada pengujian ini daya poros, torsi dan effisiensi tertinggi tercapai dengan lebar bilah $6 \mathrm{~cm}$ pada kecepatan angin $5 \mathrm{~m} / \mathrm{s}$.

\section{Energi Angin}

Energi angin merupakan salah satu sumber energi alternatif untuk pembangkitan dan sedang mendapatkan perhatian besar dari dunia karena sifatnya yang terbarukan dan ramah lingkungan. Energi angin merupakan energi angin yang murah. Hal ini dikarenakan energi angin disediakan pleh alam yang dapat menggerakkan suatu alat untuk mengubah energi kinetik angin yang nantinya dapat dimanfaatkan sebagai penggerak generator, pompa air dan sebagainya. Rotor (sudu) pada turbin angin digunakan sebagai alat pengkonversi energi angin tersebut.

\section{Turbin Angin tipe Sudu Bersirip}

Turbin angin jenis ini memiliki prinsip kerja sama dengan turbin pada umumnya. Dimulai dari pemanfaatan energi kinetik yang dimiliki oleh angin, yang kemudian dikonversikan oleh bilah menjadi energi mekanik pada poros.

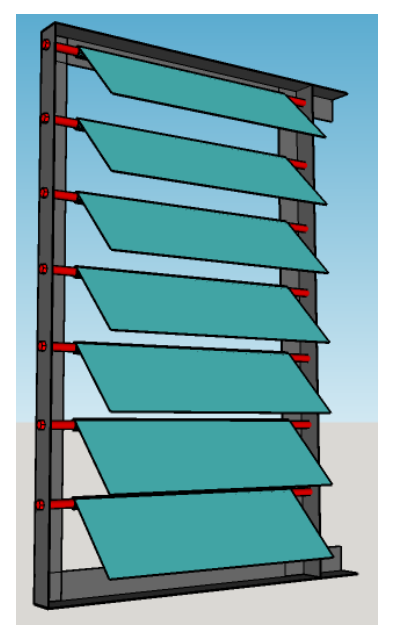

Gambar 1. Desain Sudu Turbin

Unjuk Kerja Turbin Angin tipe Sudu Bersirip 
Daya kinetik adalah daya yang diukur dengan memnghitung luas sapuan angin dan kecepatan angin.

$\mathrm{P}_{\text {kin }}=\frac{1}{2} \cdot \rho \cdot \mathrm{A} \cdot \mathrm{v}^{3}(\mathrm{Watt})$

dengan :

$\mathrm{P}_{\text {kin }}=$ Daya kinetik (Watt)

$\rho=$ Massa jenis udara $\left(\mathrm{kg} / \mathrm{m}^{3}\right)$

$\mathrm{A}=$ Luas sapuan angin $\left(\mathrm{m}^{2}\right)$

$\mathrm{v}=$ Kecepatan angin

Daya listrik adalah daya turbin yang diukur sesuai tegangan dan arus sesudah turbin angin yang di bebani oleh lampu pijar.

$\mathrm{P}_{\mathrm{g}}=\mathrm{V}$. I (Watt)

dengan :

$\mathrm{P}_{\mathrm{g}}=$ Daya Generator (Watt)

$\mathrm{V}=$ tegangan $\quad$ (volt)

$\mathrm{I}=$ arus

(Ampere)

Efisiensi sistem $\left(\eta_{\text {sistem }}\right)$ merupakan perbandingan antara efek manfaat yang digunakan yaitu daya kinetiknya dengan pengorbanan yang dilakukan yaitu daya generatornya.

$\eta_{\text {sistem }}=\frac{P g}{P \text { kin }} \times 100 \%$

dengan:

$\eta_{\text {sistem }}=$ Efisiensi sistem (\%)

$\mathrm{P}_{\mathrm{g}}=$ Daya listrik (Watt)

$\mathrm{P}_{\text {kinetik }}=$ Daya kinetik $\quad($ Watt $)$

\section{Metode Penelitian}

Bahan utama dalam penelitian ini adalah turbin angin tipe sudu bersirip. Variasi dalam penelitian ini adalah banyaknya jumlah sudu pada turbin yaitu 2, 3, 4, 5, dan 6 buah. Alatalat yang digunakan dalam penelitian adalah Blower, turbin angin sumbu vertikal bilah bersirip, generator, Multitester, Amperemeter, Digital tachometer, Anemometer, dan Beban. Sebelum melakukan penelitian perlu dilakukan persiapan, diantaranya adalah membuat sudu turbin yang akan divariasikan, menyiapkanBlower, generator, Multitester, Digital tachometer, Amperemeter, dan Anemometer. Pengambilan data dimulai setelah mengalirkan udara dari blower ke seluruh instalasi turbin angin. Kecepatan angin diatur dengan melihat anemometer, dimana kecepatan dimulai dari $7 \mathrm{~m} / \mathrm{s}$ sampai kecepatan $12 \mathrm{~m} / \mathrm{s}$.

Kecepatan angin diatur dengan mengatur jarak turbin denganblower. Pengambilan data pada penelitian ini berupa putaran pada poros turbin dengan menggunakan digital tachometer, tegangan yang dihasilkan generator menggunakan digital multitester dan arus yang dihasilkan generator menggunakan amperemeter.

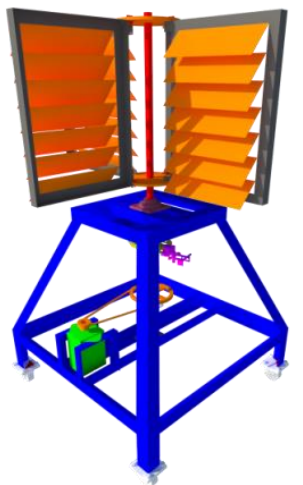

Gambar 2. Turbin Angin Tipe Sudu Bersirip

\section{Hasil dan Pembahasan}

Hasil pengujian yang sudah dilakukan menghasilkan debgan variasi jumlah sudu 2, $3,4,5$, dan 6 diperoleh data sebagai berikut :

\begin{tabular}{|c|c|c|c|c|c|c|c|}
\hline Beban & tararan Tu & taran Genera & Tegange: & Anus & Daya Generator & Daya Kinetil & fisiensi Sistem \\
\hline Watt & $\mathrm{rpm}$ & rom & volt & ampere & watt & watt & $\%$ \\
\hline 0 & 131 & 349,77 & 20 & 0 & 0 & 505,958 & 0,000 \\
\hline 5 & 123 & 328,41 & 16 & 0,3 & 4.8 & 505,958 & 0,949 \\
\hline 10 & 103 & 275,01 & 12 & 0,5 & 6 & 505,958 & $1,1,86$ \\
\hline 15 & 94 & 250,98 & 10 & 0,7 & 7 & 505,958 & 1,384 \\
\hline 20 & 85 & 226,95 & 1 & 0,9 & 6,3 & 505,958 & 1,245 \\
\hline 25 & 84 & 224,28 & 6 & 1 & 6 & 505,958 & 1,186 \\
\hline 30 & 76 & 202,92 & 5,5 & 1,2 & 6,6 & 505,958 & 1,304 \\
\hline 35 & 73 & 194,91 & 4 & 1,2 & 4,8 & 505,958 & 0,949 \\
\hline 40 & 69 & 184,23 & 3,5 & 1,2 & 4,2 & 505,958 & 0,830 \\
\hline 45 & 68 & 181,56 & 3 & 1,3 & 3,9 & 505,958 & 0,771 \\
\hline 50 & 66 & 176,22 & 2,5 & 1,3 & 3,25 & 505,958 & 0,642 \\
\hline 55 & 63 & 168,21 & 2 & 1,3 & 2,6 & 505,958 & 0,514 \\
\hline 60 & 60 & 160,2 & 2 & 1,3 & 2,6 & 505,958 & 0,514 \\
\hline 65 & 58 & 154,86 & 1,5 & 1,4 & 2,1 & 505,958 & 0,415 \\
\hline 70 & 51 & 136,17 & 1,5 & 1,6 & 2,4 & 505,958 & 0,474 \\
\hline 75 & 45 & 120,15 & 1 & 1,8 & 1,8 & 505,958 & 0,356 \\
\hline
\end{tabular}

Tabel 1. Data Pengujian dan Data Perhitungan pada Jumlah Sudu 6 dengan Kecepatan Angin 12 m/s 
Dari data yang sudah di peroleh, di buat Kinerja turbin angin dapat di analisa melalui bentuk grafik dengan variasi jumlah sudu pada kecepatan angin 12, 11, 10, 9, 8, dan 7 $\mathrm{m} / \mathrm{s}$ dapat dilihat melalui grafik sebagai berikut :

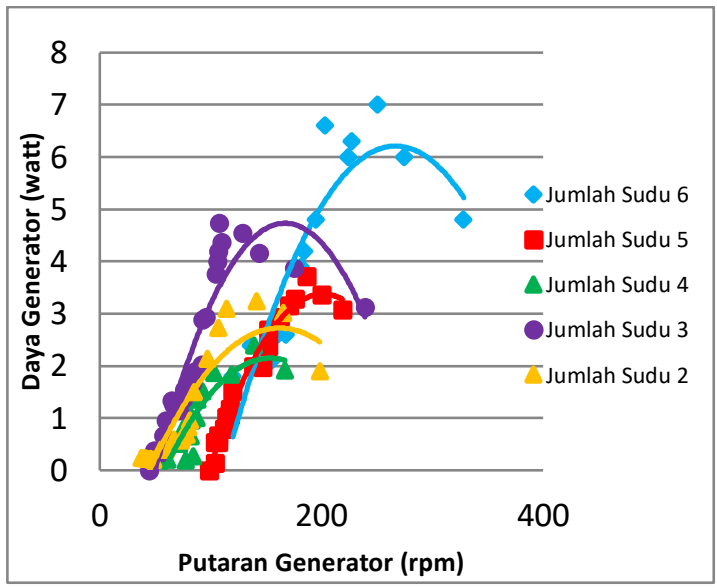

Gambar3.Grafik Hubungan Putaran Generator terhadap Daya Generator pada Kecepatan 12 m/s

Pada grafik diatas menggambarkan hubungan putaran generator terhadap daya generator pada variasi jumlah sudu $6,5,4,3$, dan 2. Terdapat 5 kurva yang mewakili masing - masing sudu pada kecepatan angin $12 \mathrm{~m} / \mathrm{s}$. Kelima kurva memiliki kecenderungan yang sama yaitu daya generator meningkat hingga mencapai titik maksimum.

Dari grafik dapat diketahui bahwa tiap sudu memiliki daya generator maksimum yang berbeda. Sudu 6 memiliki daya generator maksimum tertinggi dibandingkan dengan sudu $5,4,3$, dan 2 yaitu sebesar 6,6 watt pada putaran generator 202,92 rpm dengan pembebanan 30 watt.

Sedangkan daya generator terendah yang mampu dihasilkan sebesar 0,19 watt pada jumlah sudu 4 dengan putaran generator $77,43 \mathrm{rpm}$ pada pembebanan 80 watt.

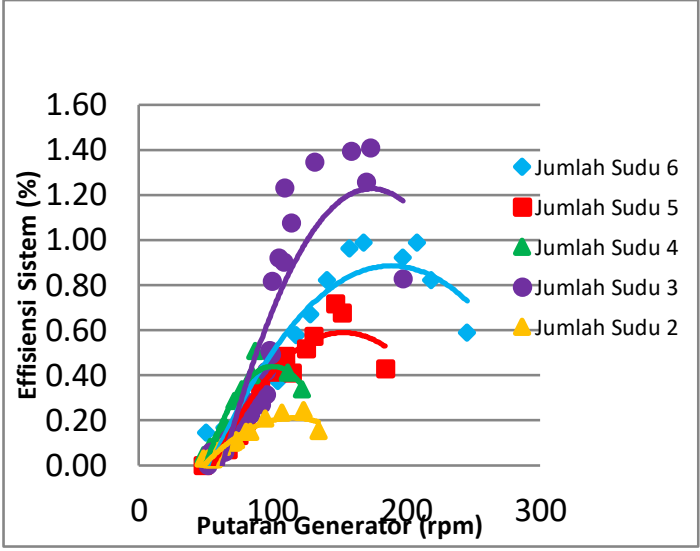

Gambar 4. Grafik Hubungan Putaran Generator terhadap Efisiensi Sistem pada Kecepatan $11 \mathrm{~m} / \mathrm{s}$

Gambar 4.4 merupakan grafik hubungan antara putaran generator terhadap efisiensi sistem pada variasi jumlah sudu $6,5,4,3$, dan 2. Dari grafik dapat diketahui efisiensi sistem tertinggi pada kecepatan angin $11 \mathrm{~m} / \mathrm{s}$ terdapat pada jumlah sudu 3 dengan nilai $1,409 \%$ dengan pembebanan 15 watt dan menghasilkan putaran generator sebesar 250,98 rpm.

Sedangkan efisiensi sistem terendah adalah $0.0262 \%$ menggunakan jumlah sudu 2 pada pembebanan 65 watt dengan putaran poros generator $56,337 \mathrm{rpm}$.

Dari grafik dapat diketahui bahwa tiap sudu memiliki efisiensi maksimum yang berbeda. Sudu 3 memiliki daya generator maksimum tertinggi dibandingkan dengan sudu $6,5,4$, dan 2.

\section{Kesimpulan}

Daya keluaran generator terbesar adalah 6,6 watt dengan tegangan sebesar 5.5 volt, dan arus 1.2 ampere, menggunakan jumlah sudu 6 dengan kecepatan angin $12 \mathrm{~m} / \mathrm{s}$ pada putaran generator 202,92 rpm.

Efisiensi sistem maksimum yang dihasilkan sebesar $1,409 \%$ menggunakan jumlah sudu 3 dengan kecepatan angin $11 \mathrm{~m} / \mathrm{s}$ pada putaran generator 173,283 rpm menghasilkan daya generator sebesar 5,49 watt.

Berdasarkan data hasil pengujian, kinerja turbin angin poros vertikal dengan sistim 
buka-tutup sirip menggunakan sudu 6 lebih efisien jika ditempatkan pada suatu daerah dengan kecepatan angin rata-rata $12 \mathrm{~m} / \mathrm{s}$. Bila menggunakan 5, 4, atau 2 buah sudu akan lebih efisien jika kecepatan anginnya $8 \mathrm{~m} / \mathrm{s}$. Dan bila menggunakan sudu 3 lebih efisien jika ditempatkan pada suatu daerah dengan kecepatan angin $11 \mathrm{~m} / \mathrm{s}$.

\section{DAFTAR PUSTAKA}

Leysen E. H, 1983, Introduction To Wind Energy, Basic and Advance Introducing To Wind Energy with Emphasisi on Water Pumping Wingmills. By Development Coorporation : Netherland

Kurniawan, Dani, Agung Widodo, dan Francisca Dewi, 2014, Pengaruh Jumlah Sirip Terhadap Unjuk Kerja Turbin Angin Tipe Bilah Bersirip. Malang: Universitas Brawijaya

Marnoto, Tjukup. 2010. Perancangan Kincir Angin Axis Vertikal Tipe Baru untukGenerator Listrik Tenaga Angin. Jogjakarta: Universitas Pembangunan Nasional Veteran

Marnoto, Tjukup. 2011. Peningkatan Efisiensi Kincir Angin Poros Vertikal Melalui System Buka Tutup Sirip Pada 3 Sudu. Jogjakarta: Universitas Pembangunan Nasional Veteran

Sularso, Ir, MSME, dan Kiyakatsu Suga, Prof., 1994. Dasar Perancangan danPemilihan Elemen Mesin, Pradnya paramita : Jakarta

Trifiananto, Muhammad. 2012. Pengaruh Panjang Bilah Terhadap Unjuk Kerja Turbin Angin Tipe Bilah Bersirip. Malang: Universitas Brawijaya Malang

Yashero, Sain Muttaqin. 2015. Pengaruh Variasi Lebar Bilah terhadap Unjuk Kerja Turbin Angin Tipe Bilah Bersirip. Malang: Universitas Brawijaya Malang

http://staff.unila.ac.id/suudi74/files/2012/09/

Materi-Poros-dengan-Beban-Puntir.pdf 